\title{
Brazil's Northeast Financing Constitutional Fund: Differentiated effects on municipal economic growth
}

\author{
Fabricio Carneiro Linhares, Ricardo Brito Soares, Marcos \\ Falcão Gonçalves and Luiz Fernando Gonçalves Viana
}

ABSTRACT

This article investigates the effects of the investments made by the Northeast Financing Constitutional Fund (FNE) on the economic growth of that region's municipalities in the decade of 2000. To that end, it uses an empirical framework based on growth models that make it possible to form convergence clubs according to the municipalities' initial development level. The results corroborate the empirical strategy and reveal the existence of four groups of municipalities, in which investment flows through the FNE have different effects on growth. In general, the FNE produces positive and significant effects in most municipalities of the Northeast, except for those whose gross domestic product (GDP) per capita was either very low or very high at the start of the decade, in which case its effects are not significant.

KEYWORDS

JEL CLASSIFICATION

AUTHORS
Economic growth, regional development, municipal government, development financing, funds, evaluation, econometric models, Brazil

O21, O40, R11

Fabrício Carneiro Linhares is Assistant Professor at the School of Graduate Studies in Economics (caen) of the Federal University of Ceará (UFC), Brazil. flinhares@caen.ufc.br

Ricardo Brito Soares is Assistant Professor at the School of Graduate Studies in Economics (caen) of the Federal University of Ceará (UFC), Brazil. ricardosoares@caen.ufc.br

Marcos Falcão Gonçalves is a Research Fellow in the Technical Office of Economic Studies of the Northeast (etene) of Banco do Nordeste do Brazil (вNB) and Professor at Faculdade Cearense, Brazil. marcosfalcaogoncalves@gmail.com

Luiz Fernando Gonçalves Viana is a researcher in the Technical Office of Economic Studies of the Northeast (etene) of Banco do Nordeste do Brasil (вnв) and Professor at Faculdade de Fortaleza (FaFor) and at the Faculty of Education and Culture of Ceará (FAECE), Brazil. luizfernandogv@bnb.gov.br 


\section{I}

\section{Introduction}

The Northeast Financing Constitutional Fund (FNE), created under Brazil's 1988 Constitution, aims to develop and improve the productive system in that zone to reduce the inequalities that have historically existed between the regions. The fund's main tool consists of expanding the supply of subsidized credit in various financing programmes, which serve firms of different sizes from various sectors. This lending programme evolved during the decades of 1990 and 2000, to become one of the main ways of stimulating regional business initiative and productive development.

The share of the FNE in total long-term financing in the Northeast reached a level of $64 \%$ between 2002 and 2009, while the investments programmed for the following years exceeded $\mathrm{R} \$ 10$ billion annually. ${ }^{1}$ As the resources of the public fund increase and it consolidates as a regional policy tool, the hope is that its capacity to generate wealth in the less developed regions increases in the same proportion - as a social counterpart-; or, to put it more pragmatically, it is hoped that the injection of a larger amount of this type of subsidized credit in local economies can foster their economic growth.

This possibility has been analysed exhaustively in the European Union, where the "structural funds" aim to boost the dynamic of growth in the less developed countries and regions of that common market. ${ }^{2}$ In the case of Brazil, empirical studies of the contribution made by regional funds to economic growth are few and far between. Apart from impact analyses which use the input-output matrix (Mesquita, 1996; Rodrigues, 1998), there are just two significant studies: Oliveira and Domingues (2005) and Resende (2012a). ${ }^{3}$ While the first of these analyses the effects of the Centre-West financing Constitutional Fund (FCO) and the North Financing Constitutional Fund (FNO) in terms of the growth differential in the beneficiary municipalities, the second examines the effects of the FNE at the same level of macroeconomic aggregation. Each of these studies uses traditional econometric models to investigate prospects for convergence between regions,

\footnotetext{
1 See Banco do Nordeste do Brasil (2011).

2 For a review of the literature, see Dall'Erba, Guillain and Gallo (2011).

3 For an analysis of the microeconomic impact of the FNE at the firm level, see Silva, Resende and Silveira Neto (2009); Soares, Sousa and Pereira Neto (2009) and Resende (2012a).
}

using the Barro and Sala-i-Martin (1992) approach; ${ }^{4}$ and both report the absence of an average effect of fund-related variables.

Nonetheless, an evaluation of the effects of public funds in the municipal sector indisputably shows that their importance and repercussions can vary across municipalities with different initial development levels. In macro-regions that display relative economic backwardness (North, Northeast and Centre-West), the municipalities are clearly heterogeneous; and this is institutionalized in the National Policy for Regional Development (PNDR) itself (Ministry of National Integration, 2005). This policy distinguishes four types of municipalities (high income, low income, dynamic, and stagnated), based on a combination of variables representing average household income and per capita GDP growth; and guidelines are provided for formulating specific lines of action adapted to each municipal type. In the context of regional funds, in addition to the plans for distributing resources to each typified group of municipalities, the Ministry of National Integration requires administrators to present monitoring reports and results in accordance with this intra-regional classification. ${ }^{5}$

This concern about the heterogeneity of growth dynamics was built into a range of non-linear models that allow for the formation of convergence clubs following the approach proposed by Durlauf and Johnson (1995). Those models make it possible to test and estimate the differentiated effects of the co-factors affecting economic growth. The formation of convergence clubs in the municipal sector, for example, identifies municipalities that have mutually similar conditional convergence possibilities, but different across the groups (clubs). It should be noted that the identification and formation of clubs in these models is not done on an ad hoc basis, but as the result of the structure of the model and the data. In other words, it is the estimation of the differentiated growth dynamics that defines the regional typologies.

\footnotetext{
${ }^{4}$ It should be noted that in each article, specific features of the respective case studies were added to the convergence models, such as spatial effects in Oliveira and Domingues (2005) and two-stage estimation in Resende (2012a).

5 Banco do Nordeste do Brasil (BNB) in the case of the FNE; Banco da Amazônia (BASA) in the case of the FNO, and Banco do Brasil (BB) in the case of the FCO.
} 
The endogenous identification of different growth patterns has previously been addressed in a number of studies on Brazil. Using dynamic panel models, Trompieri Neto, Castelar and Linhares (2008) were pioneers in analysing the process of convergence between state per capita GDP levels, with the possibility of forming clubs. Using 1985-2007 data, the authors suggest the existence of two growth-rate convergence clubs. Analogously, Cabral (2008) also identified the formation of two convergence clubs in Brazil using the methodology proposed by Phillips and Sul (2007). According to the study by Penna (2011), which approaches the topic using different methodologies, the formation of convergence clubs among Brazilian states is statistically significant, both in models that use panel data and in those using cross-section data. In another study, which uses an econometric technique and database that are similar to those adopted in this paper, Oliveira and others (2011) find evidence suggesting the existence of various convergence clubs based on the dynamic of municipal per capita GDP levels.

Against that backdrop, the present study seeks to determine whether the effects of the FNE on municipal growth can also vary according to the municipalities' initial development level. To that end, the Hansen (2000) algorithm is used for a growth model in which the variables of interest include the amount of FNE programme funds targeting the municipalities. This article's analysis of the effects of the FNE, and its heterogeneity on the economic growth of northeastern municipalities, represent a contribution to the literature on the subject.

The existence of differentiated effects not only improves the statistical properties of the estimated growth models, but also — and in particular — provides evidence of the intra-regional heterogeneity of the Northeast according to the PNDR. Nonetheless, it is possible, and even likely, that the ad hoc classifications defined in that policy do not fully coincide with those obtained from the estimated models. In that case, apart from conceptual considerations, the targeting of PNDR actions and resources could generate real inefficiencies.

This article is divided into five sections, following the introduction. Section II reviews the relation between credit and economic growth, while section III describes the FNE and its distribution in the municipalities of the Northeast. Section IV presents the data and the methodology used to estimate the FNE impact model. Section V describes and analyses the results found; and section VI concludes by offering a number of observations and inductive considerations on the subject.

\section{II}

\section{Relation between credit and economic growth}

Joseph Schumpeter was one of the pioneers in defending the notion of financial resources as promoters of economic development. He saw the financial system as providing a set of services that help channel society's saving into productive and innovative activities that form the cornerstones of economic growth.

The effects of financial resources on output growth (or on income) were formalized for the first time in studies by Goldsmith (1969); McKinnon (1973), and Shaw (1973). Whereas Goldsmith (1969) highlights the fact that the development of financial intermediation results in investments being allocated more efficiently in the economy, McKinnon (1973) and Shaw (1973) stress that this development can leverage the economy's saving rate and, consequently, its investment level. Irrespective of their theoretical perspectives, these authors conclude that the quantity and quality of services provided by the financial sector are partly responsible for inter-country growth-rate differentials.

According to De Gregorio and Guidotti (1995) and Levine (2004), this effect on the economy's activity rate can be seen in a simple way through traditional economic-growth models, where the path along which per capita output expands towards steady-state equilibrium is determined by the saving rate and the marginal productivity of capital.

In the Goldsmith (1969) approach, which is perhaps the most widely known, the range of different services supplied in the financial market — such as accepting deposits, supplying credit, processing and market data and managing risk - improve the resource allocation process and thus stimulate an increase in productivity. For example, Boyd and Prescott (1986) state that, without the financial intermediary sector, the investor 
would have to incur high costs to identify investment opportunities and evaluate the corresponding risks; and this would hinder the dynamic of resource allocation. Some authors, such as Greenwood and Jovanovic (1990); Bencivenga and Smith (1991); Levine (1992), and King and Levine (1993), use endogenous growth models to show that the analytical and research role played by the financial intermediary helps to channel resources into the projects most likely to make productive and innovation advances - in other words those that offer the highest return.

From that perspective, which is consistent with the Schumpeterian view, the supply of credit by financial institutions, based on the advice of their analysts regarding economic activity and risk indicators, can speed up growth by raising the productivity of capital. According to estimations made by Bayoumi and Melander (2008), a $2.5 \%$ reduction in the general supply of credit in an economy generates a contraction in GDP of around $1.5 \%$. That expected effect of credit in the economy is also mentioned by Keynes (1936) in his classic work "The General Theory of Employment, Interest and Money" in which he argues that credit is of fundamental importance for economic development, and not only through its direct impact on capital accumulation and knock-on effects on income distribution and innovative activity. Credit also is very important in forming expectations so that, if well directed and the good results of the investments are guaranteed, it boosts optimism in the economy.

McKinnon (1973) and Shaw (1973) view an operational financial system as essential for mobilizing saving and reducing the external financial constraints that make it difficult for firms and industries to expand. By meeting different demands in terms of the formation of an adequate portfolio, the diversity of financial services can provide a stimulus for savers. According to Jappelli and Pagano (1994), the financial sector eases the constraints imposed on borrowers in terms of future income prospects, thereby increasing the aggregate saving rate. Bourguignon (2002) argues that the uncertainties and imperfections of credit markets mean that the return to capital depends mainly on the initial wealth of the individuals involved, which severely penalizes society's investment capacity.

In short, the supply of credit, or, more generally, the development of financial resources, affects economic growth, either by more effectively directing resources towards the most productive activities (those most likely to generate productivity growth), or by increasing the saving rate and, consequently, investment. As theorized in the model proposed by Aghion, Howitt and Mayer-Foulkes (2004), growth rates in economies with a sufficiently high level of financial development will converge towards that established by the global technological frontier, whereas growth rates in all other economies will be strictly lower in the long run.

From the empirical standpoint, the relation between the availability and use of credit and economic growth varies according to the case study and the method of analysis chosen. In general, however, there is a positive causality correlation between these variables. Studies that provide evidence of this causality in Brazil include Matos (2002); Marques Jr. and Porto Jr. (2004); Chinelatto Neto (2007), and Rocha and Nakane (2007).

Nonetheless, the effects of publicly subsidized credit in terms of stimulating growth and reducing regional inequalities have been less widely explored in the literature. Although the use of subsidized credit as a regional policy tool is nothing new, interest in such credit has revived only since the formation of single markets and the rise of credit programmes for the lower social classes in various economic sectors in the 1990s. For example, in the European Union's cohesion policy, which transfers structural funds to finance lending programmes, the aim is to reduce the inequalities that exist between member countries, by supporting the formation of productive structures and promoting local markets.

The effects of Europe's structural funds on economic growth remain an open question, however. Dall'Erba and De Groot (2006) analysed 11 empirical studies conducted during the decade of 2000 and found both positive and insignificant or even negative effects. 


\section{III}

\section{The Northeast Financing Constitutional Fund and studies of its effects on growth}

In Brazil, the regional constitutional funds (FNE, FCO, FNO) are financed from the annual collection of $3 \%$ of the industrialized products tax (IPI) and income tax. Their aim is to improve the growth capacity of the lessdeveloped macro-regions (Northeast, Centre-West and North, respectively) to reduce the regional inequalities that persist in the country.

Managed by Banco do Nordeste do Brasil (BNB) since its creation in 1988 , the FNE covers 1,990 municipalities located in all states of the Northeast and in the northern part of the states of Minas Gerais and Espírito Santo which are within the jurisdiction of the Northeast Development Agency (sUDENE) (Brazil, 1999). Productive investments are financed through loan programmes whose main attraction are interest rates which are subsidized at well below market levels. ${ }^{6}$ To stimulate demand, in addition to the cash resources of bank branches, development agents are appointed to analyse and provide guidance on local opportunities for businesses in all sectors and of all sizes. ${ }^{7}$

As shown in figure 1, the volume of resources invested has grown throughout the fund's existence - particularly since 2002, reflecting both the faster growth of the economy and government incentives aimed at expanding the availability of credit for the Northeast region.

A review of the sectoral distribution of the resources in the period 2002-2008 shows that the FNE has financed enterprises in all sectors of the economy. Nonetheless, the rural sector absorbed $46.5 \%$ of total funding, owing to the specific dynamic of the northeastern economy, which has traditionally been dominated by agriculture. In second place were manufacturing and tourism, which accounted for $22.4 \%$ of the resources invested, followed by the commerce and services sector with $15.5 \%$ (see figure 2).

In terms of the size of the beneficiaries, large firms received $54.2 \%$ of the resources in the period studied,

\footnotetext{
6 The resulting interest-rate spread is even greater for investments targeting the least developed regions, such as the semi-arid zone, and the smallest firms.

${ }^{7}$ For a retrospective analysis of the FNE, see Ministry of National Integration (2010).
}

followed by mini/small firms (32.6\%) and then mediumsized firms (13.2\%) (see figure 3 ).

Map 1 shows the cumulative amount of funding distributed to each municipality in that period by value intervals defined for each quintile (in R \$ at 2007 prices). ${ }^{8}$ Although all municipalities benefited, the amount received varies considerably from one to another, ranging from $\mathrm{R} \$ 15,900$ in Santa Cecília-PB to $\mathrm{R} \$ 1.3$ billion in Fortaleza-CE ${ }^{9}$ on average per year. The basic issue raised by these figures is whether the municipalities that receive proportionally more resources are in fact going faster owing to the financing.

Few studies have been made of the effectiveness of the constitutional funds. Oliveira and Domingues (2005) seek to determine whether the resources of the Centre-West and North Constitutional Funds have helped reduce growth-rate disparities in the municipalities of those regions with respect to the national average. For that purpose, they use a traditional growth model that includes spatial effects representing economic externalities. The results of this study did not provide evidence that the financing funds have had significant effect in reducing inequalities.

Resende (2012a) reached qualitatively similar conclusions for the FNE in a study of the latter's effects on the economic growth of municipalities in the area of operation of Banco do Nordeste. As a qualitative variable of the FNE, the study uses the ratio between the volume of fund resources (manufacturing, services and commerce programmes) and the gross domestic product (GDP) of the municipalities in the periods 2000-2001 and 2000-2003; and, as the result variable (macroeconomic impact), it uses per capita GDP growth in the periods between 2002 and 2006. The control variables used were indicators of education (average years of schooling), health (child

\footnotetext{
8 Values deflated by the general price index (IGP-DI); the total volume of funding in the period was roughly R $\$ 24.9$ billion.

${ }^{9}$ It should also be noted that $15.38 \%$ of the resources were destined for municipalities defined as low-income in the PNDR classification, $31.12 \%$ for municipalities whose economies were stagnating, $27.72 \%$ for the dynamic ones, and $25.78 \%$ to high-income municipalities. In addition, with regard to the regional distribution, just $34.76 \%$ of the resources were destined for municipalities in the semiarid region of the Northeast.
} 
FIGURE 1

Annual contracting by the Northeast Financing Constitutional Fund, 1994-2008 (Millions of $R \$$ at 2008 prices)

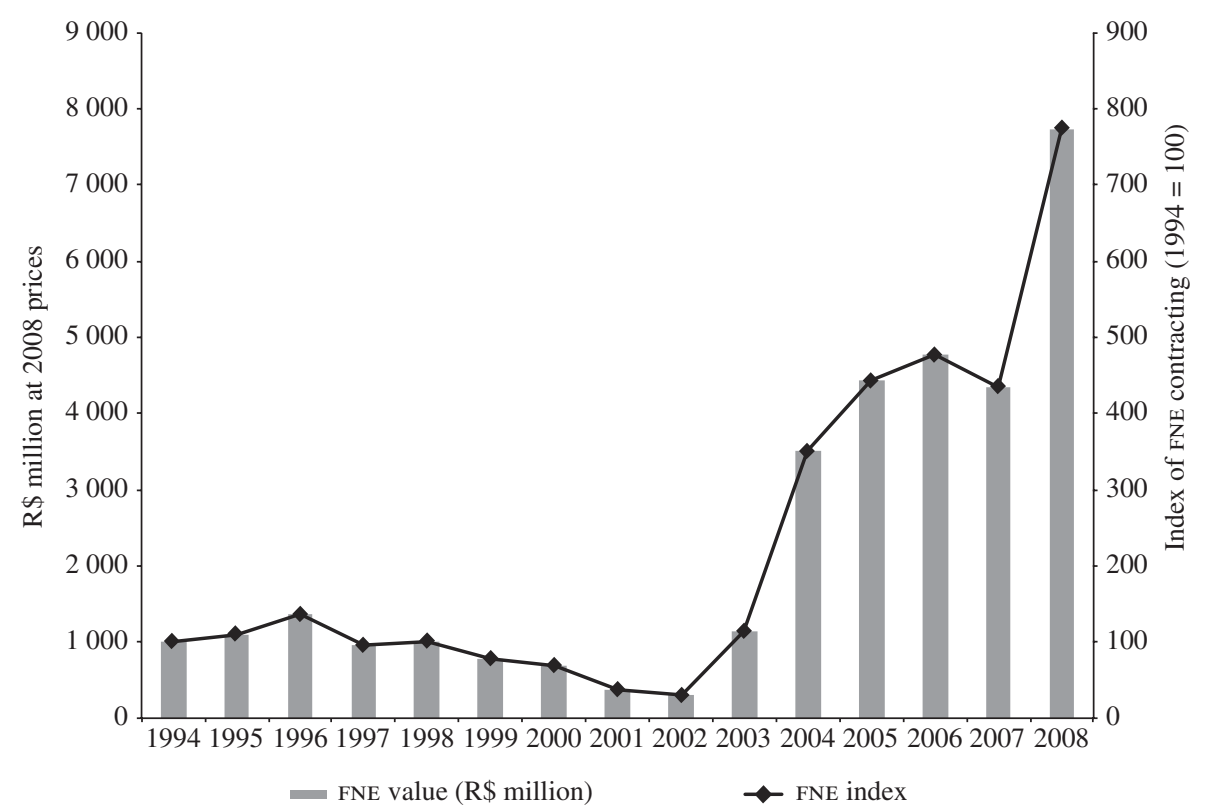

Source: Ministry of National Integration, 20 Anos de Fundos Constitucionais de Financiamento (FCO - FNE- FNO), Brasilia, 2010.

FIGURE 2

Contracting by the Northeast Financing Constitutional Fund by sector, 2000-2008

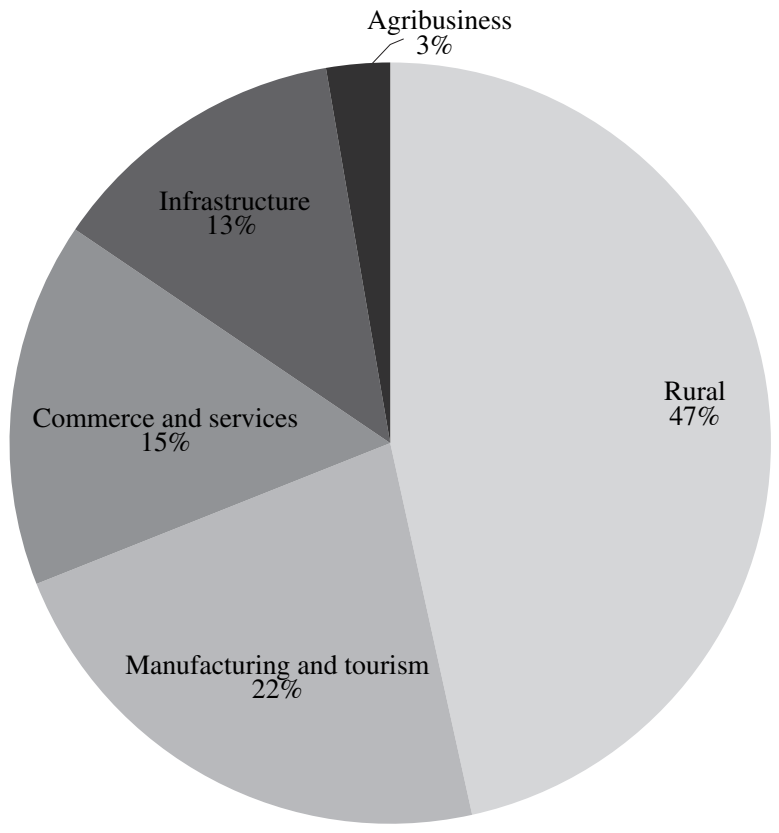

Source: prepared by the authors on the basis of data from Banco do Nordeste do Brasil. 
FIGURE 3

Contracting by the Northeast Financing Constitutional Fund by beneficiary size, $2000-2008$

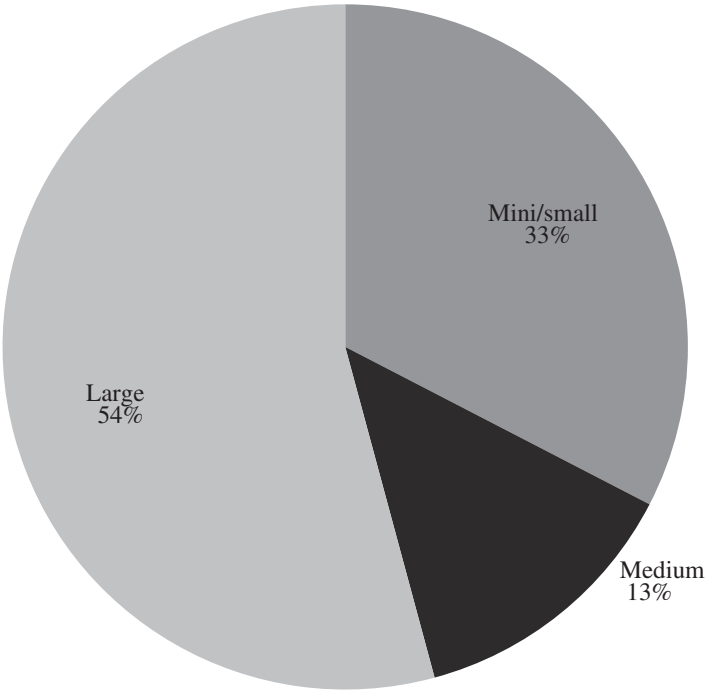

Source: prepared by the authors on the basis of data from Banco do Nordeste do Brasil.

MAP 1

Cumulative investments of the North-East Financing Constitutional Fund, by municipality, 2002-2008, 2002-2008

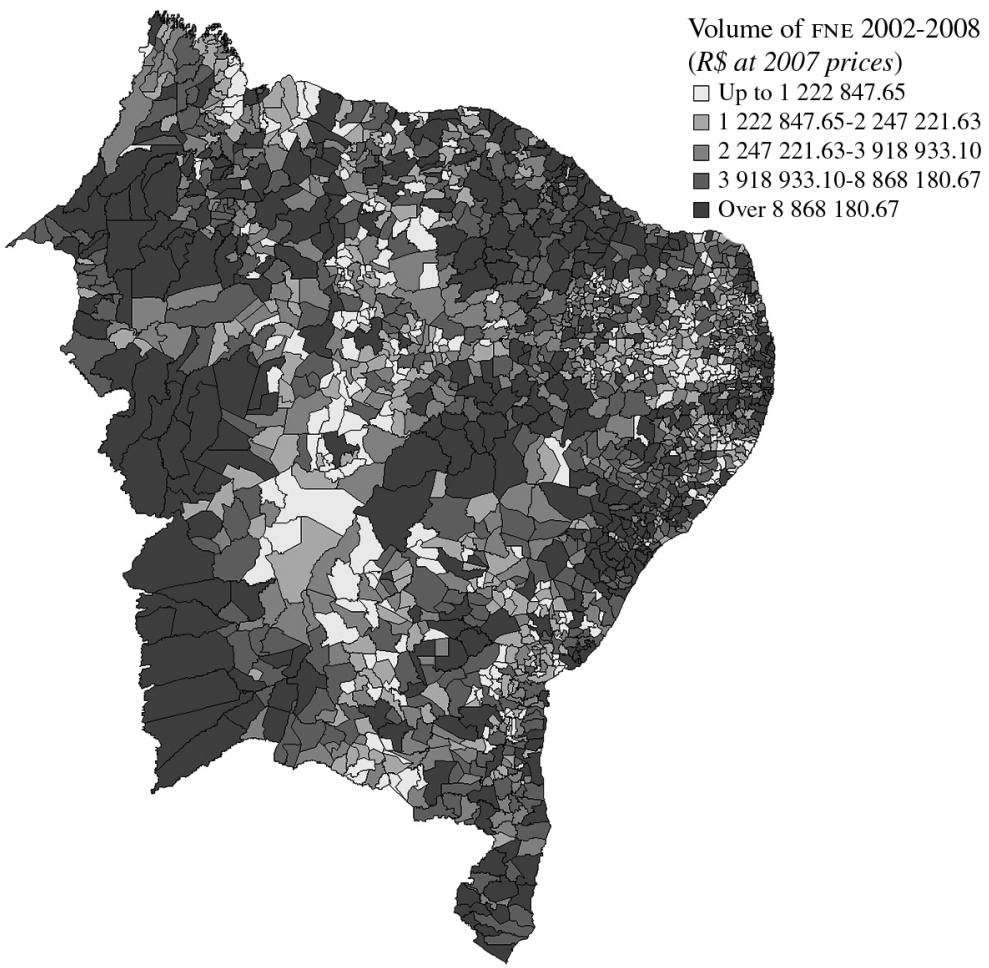

Source: prepared by the authors on the basis of data from Banco do Nordeste do Brasil. 
mortality), demography (population density), housing (infrastructure index) and transport (the cost of transport measured by the linear distance to São Paulo), together with the variable indicating convergence (per capita GDP in 2002). Controlling for the potential problem of FNE endogeneity with a model estimated in two stages, the author does not find a positive and statistically significant effect of the FNE on economic growth.

Although this article shares the theoretical model of economic growth used in Resende (2012a), its empirical verification differs in several respects. Firstly, the period of GDP growth analysed is longer (2002-2008), and it includes an episode of high economic growth which could have been induced by FNE investments reaching maturity. ${ }^{10}$ Secondly, it took account of FNE contributions to all programmes and not just those of the manufacturing sector. Although the latter absorbed the largest share of the value of FNE resources over the period analysed in aggregate, ${ }^{11}$

10 The period of analysis was chosen to end in 2008 because of limitations in data available on municipal GDP when this research was carried out.

11 In addition to the manufacturing, commerce and services programmes, the FNE includes programmes for the rural sector, agribusiness and infrastructure. Historically, the rural sector has accounted for the largest volume of contracting. this may not occur homogeneously throughout the municipal sector. For that reason, other sectoral dimensions of the FNE also need to be tested as key variables of the impact research.

Lastly, the effects of the FNE may be felt differently across the municipalities of the Northeast. For example, verification of the effects may depend on the amount of resources received in relation to the size of the municipal economy, or some other municipal economic indicator. The variability or heterogeneity of the macroeconomic effects of the FNE within the group of municipalities of the Northeast is a plausible possibility, which needs to be tested empirically. ${ }^{12}$ If valid, their omission from the econometric model leads to biased and inconsistent estimates.

This article seeks to address the foregoing concerns by estimating a non-linear growth model, which captures the heterogeneities in the effects according to the initial development level of the municipalities, and covers a period of rapid growth for the Northeast (2002-2008).

\footnotetext{
12 The heterogeneity of the effects of the FNE between municipalities was pointed out by Resende (2012b) in a study for the manufacturing sector of Ceará.
}

\section{IV \\ Methodology and database}

\section{Econometric model}

The effects of the FNE on the macroeconomic indicators of the region's municipalities are evaluated using a similar methodology to that used in research in the economic growth area, the main references for which are Baumol (1986) and Barro and Sala-i-Martin (1991 and 1992). In those studies, the hypothesis that the per capita GDP of the economies tends to converge over time is analysed using a regression model which converts the average rate of growth of per capita GDP between the initial and final period final $\left(\dot{y}_{i, T}\right)$ into a function of its level in the initial period $\left(y_{i, 0}\right)$,

$$
\dot{y}_{i, T}=\alpha_{1}+\alpha_{2} \ln \left(y_{i, 0}\right)+\varepsilon_{i}
$$

where:

$\alpha_{1}$ and $\alpha_{2}$ are parameters;

$\varepsilon_{i}$ is the error term; and

$i$ is the index referring to the unit of observation (economy).

If $\alpha_{2}$ turns out to be negative and statistically significant in the context of the equation (1), the economies display a growth pattern that is consistent with the theory of absolute convergence.

In later studies, the empirical growth model was made more flexible to control for possible long-term differences in the per capita GDP levels of the economies. That approach, known as the augmented Solow model, was discussed initially in Mankiw, Romer and Weil (1992) and was adopted in several subsequent studies as part of research on conditional convergence. The regression model would have the following form: 


$$
\dot{y}_{i, T}=\alpha_{1}+\alpha_{2} \ln \left(y_{i, 0}\right)+B^{\prime} X_{i}+\varepsilon_{i}
$$

where:

$X_{i}=\left[x_{l i} \ldots x_{k i}\right]$ is a vector with $k$ conditioning (control) variables;

$B^{\prime}=\left[\begin{array}{llll}b_{1} & b_{2} & \ldots & b_{\mathrm{k}}\end{array}\right]$ is the vector of partial gradient coefficients.

The set of regressors comprising $X_{i}$ is wide ranging and includes variables that characterize political, economic and social aspects of the economies. For a detailed list of those potential regressors, see Durlauf and Quah (1999) and Durlauf, Johnson and Temple (2004).

To evaluate the aggregate effect of the FNE on the municipalities of the Northeast, the following modifications to regression models (1) and (2) were adopted as an initial scheme:

$$
\begin{gathered}
\dot{w}_{i, T}=\beta F_{i}+a_{1}+a_{2} \ln \left(w_{i, 0}\right)+\varepsilon_{i}, \\
\dot{w}_{i, T}=\beta F_{i}+a_{1}+a_{2} \ln \left(w_{i, 0}\right)+A^{\prime} X_{i}+\varepsilon_{i},
\end{gathered}
$$

where:

$\dot{w}_{i, T}$ is the average rate of growth of macroeconomic indicator $w$ between 2002 and 2008; and $w_{i, 0}$ is its value in 2002;

$F_{i}$ is a measure capturing the intensity of FNE policy in the municipality;

$\beta$ is the parameter that reports the effect of the FNE on the growth of $w$;

$X_{i}=\left[x_{3 i} x_{4 i} \ldots x_{k i}\right]$ is a vector with $k-2$ control variables (defined in the following section);

$A^{\prime}=\left[\begin{array}{llll}\alpha_{3} & \alpha_{4} & \ldots & \alpha_{k}\end{array}\right]$ is the vector of the other partial gradient coefficients;

$\varepsilon_{i}$ is the error term; and

$i$ is the index referring to the $i$-th municipality.

In equations (3) and (4), the effects of the FNE are measured by their capacity to promote per capita GDP growth. If $w$ is per capita GDP, and $F$ is the amount of FNE financing per capita, the parameter $\beta$ can be interpreted as a growth-FNE elasticity, whereby a $1 \%$ change in $F$ produces a change of $\beta$ percentage points in the rate of growth of $w$. Given that the financing provided by the FNE is generally used to promote the local economy and expand its productive infrastructure, its investment in a given municipality would be expected to raise the rate of growth of income, employment, and the average wage $(\beta>0)$.
In the analysis of the macroeconomic effects of the FNE, one of the constraints on equations (3) and (4) is the assumption that the effects are equal in all units of the cross-section. In other words, the parameter representing the effects of the FNE, $\beta$, is the same for all municipal economies. Nonetheless, municipalities with different development levels and productive structures may be affected differently by the FNE in practice.

Although recent, the idea that the parameters in the economic growth models vary between the economies has been widely discussed. Studies by Azariadis and Drazen (1990) and Durlauf and Johnson (1995), for example, modify the traditional growth model by easing the assumption that the production function is convex, and suggest the possibility of multiple steady states for per capita GDP. In the time path of income, the effects of the determinants of growth would be heterogeneous, depending on the set of specific features of the economies.

To take account of this possibility in the FNE study, equations (3) and (4) were transformed to incorporate threshold effects as proposed by Hansen (2000):

$$
\begin{gathered}
\dot{w}_{i, T}=\left(\beta_{1} F_{i}+a_{11}+a_{21} \ln \left(w_{i, 0}\right)\right) \cdot I_{1}\left\{y_{i, 0} \leq \gamma_{1}\right\}+ \\
\left(\beta_{2} F_{i}+a_{12}+a_{22} \ln \left(w_{i, 0}\right)\right) \cdot I_{2}\left\{\gamma_{1}<y_{i, 0} \leq \gamma_{2}\right\}+\ldots, \\
\left(\beta_{J} F_{i}+a_{1 J}+a_{2 J} \ln \left(w_{i, 0}\right)\right) \cdot I_{J}\left\{y_{i, 0}>\gamma_{J-1}\right\}+\varepsilon_{i}
\end{gathered}
$$

$$
\begin{gathered}
\dot{w}_{i, T}=B_{1}^{\prime} Z_{i} \cdot I_{1}\left\{y_{i, 0} \leq \gamma_{1}\right\}+B_{2}^{\prime} Z_{i} \cdot I_{2}\left\{\gamma_{1}<y_{i, 0} \leq \gamma_{2}\right\}+\ldots, \\
B_{J-1}^{\prime} Z_{i} \cdot I_{J-1}\left\{\gamma_{J-2}<y_{i, 0} \leq \gamma_{J-1}\right\}+ \\
B_{J}^{\prime} Z_{i} \cdot I_{J}\left\{y_{i, 0}>\gamma_{J-1}\right\}+\varepsilon_{i},
\end{gathered}
$$

where:

$Z_{i}=\left[F_{i} 1 \ln \left(w_{i, 0}\right) x_{3 i} X_{4 i} \ldots x_{k i}\right]$ is a vector of regressors;

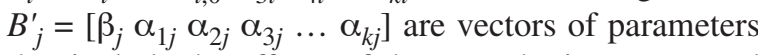
that include the effects of the FNE, the intercepts and the partial gradient coefficients;

$I_{j}\{\cdot\}$ are indicator functions with $I_{j}\{\Psi\}=1$ in the event of $\Psi$ occurring; and

$I_{j}\{\Psi\}=0$ otherwise;

$y_{i, 0}$ is the threshold variable that affects changes in the parameters; value of per capita GDP in 2002;

$\gamma_{j}$ are the threshold parameters;

$j=1, \ldots, J$ is the index relating to the regime or group of municipalities that share the same values of the parameters $B_{j}$, and $\varepsilon_{i}$ is the error term. 
These models make it possible to evaluate the macroeconomic effects of the FNE in $J$ possible groups of municipalities, selected according to municipal per capita GDP in 2002 (a proxy variable for the economy's development level). Heterogeneity in the effect of the FNE is characterized by the variation in the $\beta_{j}$ coefficients and, consequently, in the $B_{j}$ vectors; in other words, the influence of all determinants of $\dot{w}_{i, T}$. If the parameters are invariant, $B_{1}=\ldots=B_{J}$, the regression models would be reduced to the initial forms expressed by equations (3) and (4).

The variation in the effects of the FNE is therefore investigated through tests on constraints on the parameters vector $\beta_{j}$, conditional on the indicators functions $I_{j}\{\cdot\}$. In the process of estimating the models, those tests make it possible to see the relevant number of groups in the evaluation of the effects of the FNE and determine the initial per capita GDP level that defines each group. In other words, along with estimations of the parameters $\gamma_{j}$, the value of $J$ is obtained statistically.

To simplify the explanation of the estimation of the model and determination of $J$ (the number of groups), equation (6) is considered with just two possible groups. Group 1 would consist of municipalities with an initial per capita GDP below $\gamma_{1}$, while group 2 would consist of municipalities with an initial per capita GDP above $\gamma_{1}$.

$\dot{w}_{i, T}=B_{1}^{\prime} Z_{i} \cdot I_{1}\left\{y_{i, 0} \leq \gamma_{1}\right\}+B_{2}^{\prime} Z_{i} \cdot I_{2}\left\{y_{i, 0} \leq \gamma_{1}\right\}+\varepsilon_{i}$.

Equation (7) can be rewritten as

$$
\dot{w}_{i, T}=\Phi\left(\gamma_{1}\right)^{\prime} Z_{i}+\varepsilon_{i}
$$

with $\Phi\left(\gamma_{1}\right)^{\prime}=\left[B_{1}^{\prime} I_{1}\left\{y_{i, 0} \leq \gamma_{1}\right\} \quad B_{2}^{\prime} I_{2}\left\{y_{i, 0}>\gamma_{1}\right\}\right]$.

Equation (8) is estimated using the methodology proposed in Hansen (2000). Let $P$ be the interval formed by the minimum and maximum of the threshold variable in the sample, $P=\left[\min _{i}\left\{y_{i, 0}\right\}, \max _{i}\left\{y_{i, 0}\right\}\right]$. For $\mu \in(0,1), \Gamma$ is defined as a discreet version of the $P$ space with $100 . \mu \%$ of its initial and final values excluded symmetrically, ${ }^{13}$ formed by $m$ equidistant points. Firstly,

13 The exclusion of those values is a necessary condition for the good performance of the estimation of the parameters and execution of the tests. the parameters vector $\Phi$ is estimated by least squares for all $\gamma_{1} \in \Gamma$, forming $m$ values for the sum of the square of the residuals $S\left(\gamma_{1}\right)=\sum_{i}\left(\dot{w}_{i, T}-\tilde{\Phi}\left(\gamma_{1}\right)^{\prime} Z_{i}\right){ }^{2}$. Then, the estimations of $\Phi$ and $\gamma_{1}$ are obtained, finding the value of $\gamma_{1} \in \Gamma$ that minimizes the function $S\left(\gamma_{1}\right),\left\{\hat{\Phi}, \hat{\gamma}_{1}\right\}=\underset{\gamma_{1} \in \Gamma}{\operatorname{argmin}} S\left(\gamma_{1}\right)$.

That procedure produces two sets of estimated coefficients, $\hat{B}_{1}$ for municipalities with $\left\{y_{i, 0} \leq \hat{\gamma}_{1}\right\}$ and $\hat{B}_{2}$ from those with $\left\{y_{i, 0}>\hat{\gamma}_{1}\right\}$. The test of heterogeneity of the parameters under the threshold effect, $B_{1} \neq B_{2}$, which indicates whether statistically there are two different groups of municipalities (given the context of the regression model), uses the Lagrange test statistic proposed by Hansen (1996). The critical values of that statistic, which is robust to heteroscedasticity, are found using a bootstrap procedure. If $B_{1} \neq B_{2}$, the conclusion is that there are two groups in which the FNE and other control variables produce different effects on the rate of growth of $w$.

If two groups are found to exist, the analysis then tests for the existence of three groups. In that case, the vector of parameters of the equation (8) is given by

$$
\begin{aligned}
& \Phi\left(\gamma_{1}, \gamma_{2}\right)^{\prime}= \\
& {\left[B_{1}^{\prime} I_{1}\left\{y_{i, 0} \leq \gamma_{1}\right\} B_{2}^{\prime} I_{2}\left\{\gamma_{1}<y_{i, 0} \leq \gamma_{2}\right\} B_{3}^{\prime} I_{3}\left\{y_{i, 0}>\gamma_{2}\right\}\right]}
\end{aligned}
$$

or

$$
\begin{aligned}
& \Phi\left(\gamma_{1}, \gamma_{2}\right)^{\prime}= \\
& {\left[B_{1}^{\prime} I_{1}\left\{y_{i, 0} \leq \gamma_{2}\right\} B_{2}^{\prime} I_{2}\left\{\gamma_{2}<y_{i, 0} \leq \gamma_{1}\right\} B_{3}^{\prime} I_{3}\left\{y_{i, 0}>\gamma_{1}\right\}\right] .}
\end{aligned}
$$

The parameters vector $\Phi$ is estimated by least squares for all $\gamma_{2} \in \Gamma$, with $\left|\gamma_{2}-\gamma_{1}\right| \geq \delta>0$, forming several values for the sum of the square of the residuals $S\left(\gamma_{1}, \gamma_{2}\right)=\sum_{i}\left(\dot{w}_{i, T}-\tilde{\Phi}\left(\gamma_{1}, \gamma_{2}\right)^{\prime} Z_{i}\right) ;^{2}$ and, similarly, $\Phi, \gamma_{1}$ and $\gamma_{2}$, are estimated by minimizing the function $\mathbf{S}\left(\gamma_{1}, \gamma_{2}\right)$ in the space of the threshold values. Lastly, the three-group model is compared to the two-group model using the Lagrange multiplier test.

\section{Data}

The sample used in this study contains data on the per capita GDP of the municipalities of the Northeast, the amount of resources from FNE programmes invested in those localities, and the variables (co-factors) that characterize and influence the composition of municipal 
economies, according to the growth model proposal (4). All monetary variables are deflated by the general price index with a base year of 2007. ${ }^{14}$

In the regression equations, $\dot{w}_{i, T}$ and $w_{i, 0}$ then represent the average rate of growth of per capita GDP in each municipality in the period 2002-2008 and the level of per capita GDP of each municipality in 2002. It is important to note that the value of per capita GDP in 2002 is also used as a threshold variable; in other words, the variable on which the groups of municipalities with similar growth patterns will (or will not) be formed. ${ }^{15}$

The variable on which the effect of FNE resources on the growth of those indicators will be evaluated, $F_{i}$, is the annual per capita average of total FNE financing in the period 2002-2006. ${ }^{16}$ Thus, at least two years are allowed to capture the maturity of the investments on the growth of the municipality; and, from the methodological standpoint, problems of policy endogeneity in the model estimations are avoided. ${ }^{17}$

As the FNE consists of several financing programmes targeting different aspects of the market, the fund's effect in a given municipality may depend on the type of municipality and the specific type of programme developed most intensively in that location. Programmes such as the National Programme for the Strengthening of Family Agriculture (PRONAF) and FNE-Industrial have different clientele whose action and contribution to market growth is obtained through different mechanisms. For example, it is more likely that the first produces effects on demand, because the subsistence economy would not involve progress in the productive structure, despite the fact that the accumulation of small-scale family farmers promotes the formation of organized productive clusters. In contrast, FNE-Industrial would

\footnotetext{
14 See Ipeadata [online] www.ipeadata.gov.br.

15 The per capita GDP values for the municipalities were obtained from Ipeadata.

16 The values of the FNE related to the municipalities were taken from ETENE/BNB.

17 The results of the models estimated with that variable for the period 2002-2005 were quite similar.
}

have effects on the supply side, because in many cases it represents the expansion of the productive structure itself. Although the multiplier effects of FNE-Industrial are strong, PRONAF participation in the growth of local economies cannot be ruled out. For that reason, it was decided to use the total FNE to represent the policy variable and not just the resources provided by the industrial programmes.

The variables $x_{3 i} x_{4 i} \ldots x_{k i}$, presented in subsection 1 , are other determinants of economic growth or control variables used in various empirical studies in this line of research. ${ }^{18}$ They are chosen because of their appropriateness for the study and their availability for all municipalities in the period 2002-2008. Consequently, the following variables were selected: the logarithm of the mean of the ratios between current expenditure and municipal GDP in 2002 ( gov), representing the size of the government; the logarithm of the number of years' schooling of individuals of at least 25 years of age in $2000(e d u)$, which represents the education and human capital conditions of the municipalities; the logarithm of the sum of the average population growth rate in the municipalities in the period 2002-2008 (n); the rate of growth of technology and the depreciation rate $(\delta+d)=5 \%$; the proportion of households with piped water (infra), which measures infrastructure; the total volume of credit operations ( $o p c)$; the municipality's distance from the respective state capital (dist), which captures geographic and indirect effects; and the binary variable indicating whether the municipalities located in a semiarid region (semi). A more detailed description of these variables and their sources can be found in table A.1 of the annex.

It should be noted that the credit operations variable provides an important control for identifying the effect of the FNE on growth in the municipalities. By controlling the potential effects of total credit channelled to the municipalities, the effect of the FNE is distinguished from other bank financing alternatives.

\footnotetext{
18 See the review made in Tsangarides (2005).
} 


\section{V}

\section{Results}

This section describes the main results of the linear models (1) and (2), referred to as global, and the models with the threshold effect (3) and (4). The models were estimated using the methodology described in section IV, along with test statistics and estimations of standard deviations that are robust to heteroscedasticity. ${ }^{19}$ Although the linear models are presented, these were rejected by the Lagrange multiplier test, when compared to the models with a threshold effect, thereby showing that the latter are statistically more appropriate for describing the data.

The complete results of the models are shown in the annex (see tables A.2 and A.3), whereas the tables below only show the effects of the FNE on the average rate of growth of per capita GDP. The models are based on a different number of observations (municipalities), because the sample selection was based on the availability of data for all of the variables in the estimated regression equation.

It should be remembered that the threshold variable used in the analysis is the natural logarithm of initial per capita GDP, which, in this study, corresponds to 2002. The use of initial per capita GDP as that variable is very common in similar studies; and, in empirical models, it serves as a proxy variable for dividing the municipalities into groups according to the development status of their economies at the start of the growth process being analysed. Thus, in the case of models (5) and (6), the effects of the FNE could be interpreted as being separated into groups of municipalities with different development levels.

Tables 1 and 2 show the sample size (number of municipalities) and report the estimations of the effects of the FNE on the average growth rate of per capita GDP, corresponding to the global model and the model with the threshold effect, respectively, depending on whether or not the control variables $X_{i}$ are used. When the controls are included, the sample is reduced from 1,790 to 1,228 municipalities, because many of them do not have data for the period analysed.

It is interesting to note that, in the traditional models, the effect of the FNE was positive and significant, with and without controls relating to the determinant co-factors of economic growth. This is a qualitatively different result from that found in Resende (2012a).

19 An adapted version of the Gauss routine, provided by Hansen (2000), was used.
TABLE 1

Estimations of the global model

(Per capita GDP)

\begin{tabular}{lcc}
\hline & $\begin{array}{c}\text { Number of } \\
\text { municipalities }\end{array}$ & $\begin{array}{c}\text { Effect of } \\
\text { the FNE }\end{array}$ \\
\hline $\begin{array}{l}\text { Result without controls }\left(X_{i}\right) \\
\text { (Model 1) }\end{array}$ & 1790 & $0.082^{*}$ \\
$\begin{array}{l}\text { Result with controls }\left(X_{i}\right) \\
\text { (Model 2) }\end{array}$ & 1228 & $0.085^{*}$ \\
\hline
\end{tabular}

Source: prepared by the authors.

* Significant at $5 \%$.

FNE: Northeast Financing Constitutional Fund GDP: Gross domestic product.

TABLE 2

Estimations of the model with threshold effect

(Per capita GDP)

\begin{tabular}{lcc}
\hline Group (interval for $\left.y_{i, 0}\right)$ & $\begin{array}{c}\text { Number of } \\
\text { municipalities }\end{array}$ & $\begin{array}{c}\text { Effect of } \\
\text { the FNE }\end{array}$ \\
\hline Result without controls $\left(X_{i}\right)$ (Model 3) & & \\
Below R\$ 4105 & 1493 & $0.067^{*}$ \\
Above R\$ 4 105 & 297 & $0.117^{*}$ \\
Result with controls $\left(X_{i}\right)$ (Model 4) & & \\
Below R\$ 2 143 & 204 & -0.007 \\
Between R\$ 2143 and R\$ 3 866 & 794 & $0.078^{*}$ \\
Between R\$ 3866 and R\$ 7406 & 177 & $0.109^{* *}$ \\
Above R\$ 7406 & 55 & 0.173 \\
\hline
\end{tabular}

Source: prepared by the authors.

*Significant at $5 \%$;* significant at $10 \%$.

FNE: Northeast Financing Constitutional Fund. GDP: gross domestic product.

Nonetheless, the Lagrange multiplier tests rejected the global models in favour of the models with the threshold effect, with two groups without $\left(X_{i}\right)$ controls and four groups with them. In the first case, one group consists of municipalities with an initial per capita GDP of less than $\mathrm{R} \$ 4,105$ (1,493 municipalities), and the other has municipalities with an initial per capita GDP above that level (297 municipalities). The statistically significant effects of the FNE on growth are 0.067 in the case of the lower-income group and 0.117 in relation to the higher- income group. This means that the volume of FNE resources per capita produces a greater effect on income growth in municipalities that are more economically developed. In the municipalities of the first 
group, every $10 \%$ increase in FNE financing per capita generates an increase of 0.67 percentage points in the average growth rate of per capita GDP, compared to an increase of 1.17 percentage points in the second group.

According to the global model without controls (see table 1), that increase would be 0.82 percentage points in all municipalities. In contrast, one of the advantages of the model with a threshold effect is the possibility of establishing differences in the effects of the FNE and identifying the variable which determines that differentiation. The results of the model with the threshold effect but without controls in this study suggest that the influence of FNE funding on economic growth is more intensive in the higher per-capita-income municipalities. This could reflect their more dynamic economic activity and greater maturity of their entrepreneurs.

Controlling for other growth co-factors, the first group consists of municipalities with an initial per capita GDP below R \$ 2,143 (204 municipalities); the second consists of municipalities with an initial per capita GDP equal to or greater than $\mathrm{R} \$ 2,143$ but less than $\mathrm{R} \$ 3,866$ (794 municipalities); the third comprises those with an initial per capita GDP equal to or greater than $\mathrm{R} \$ 3,866$ but less than $\mathrm{R} \$ 7,406$ (177 municipalities; and the fourth, those with an initial per capita income of $\mathrm{R} \$ 7,406$ or more (55 municipalities).

Apart from the intermediate groups (the second and third) the estimation of the effects on the FNE on per capita GDP growth is not statistically significant. It is worth noting that the group-average effects are captured independently of the aggregate amount of resources received by them. For example, table 3 shows that the groups in which the effects of the FNE were not statistically significant are those that received the smallest and largest amounts of resources per capita.

TABLE 3

Volume of the FNE by growth clubs, 2002-2006

\begin{tabular}{lrc}
\hline $\begin{array}{l}\text { Clubs } \\
\text { (Per capita GDP })\end{array}$ & $\begin{array}{c}\text { Volume of FNE } \\
(R \$ \text { at } 2007 \text { prices })\end{array}$ & $\begin{array}{c}\text { Average per capita } \\
\text { volume of FNE } \\
(R \$ \text { at 2007 prices })\end{array}$ \\
\hline R\$ 2 143 & 452397355.43 & 199.91 \\
R\$ 2 143-R\$ 3 866 & 3281973904.51 & 254.02 \\
R\$ 3 866-R\$ 7 406 & 2364298679.18 & 314.32 \\
R\$ 7 406 & 2700014000.88 & 1716.11 \\
Total & 8798683940.00 & 319.20 \\
\hline
\end{tabular}

Source: prepared by the authors.

FNE: Northeast Financing Constitutional Fund. GDP: gross domestic product.

In the groups of municipalities in which the FNE had a significant effect, the general patterns is quite similar to the case in which controls are not used in the regression model. In the second group, every $10 \%$ increase in FNE financing per capita generates a 0.78 percentage point increase in the average growth rate of per capita GDP in the municipalities, whereas in the third group, the corresponding increase is 1.09 percentage points. This confirms the evidence that the effect of FNE financing rises according to the initial income level of the municipalities.

Another important finding is that the effects of the FNE are found in the vast majority of the most representative municipalities - those that comprise the second and third groups, representing roughly $79 \%$ of the sample- The endogenous distinction between municipalities that report significant effects of the FNE, and those that do not, allows for an effectiveness analysis with respect to the municipality groups classified according to the PNDR (Ministry of National Integration, 2005).

The four groups formed in this study can be referred to as growth clubs, because the municipalities comprising them display similar patterns of per capita GDP growth, bearing in mind the joint influence of the model's other co-factors. It is therefore to be expected that FNE financing would produce differentiated effects in municipalities with different initial per capita GDP levels. A comparison between the municipalities comprising the clubs defined in this study with those classified according to the PNDR is shown in table 4.

In table 4, the rows represent the clubs formed by initial per capita GDP, whereas the columns relate to the classification of the municipalities according to the PNDR. These can be classified as low income, stagnated, dynamic and high income, by making an ad hoc tabulation that combines initial per capita income and growth reported in the decade of $1990 .{ }^{20}$ Of the 397 municipalities in the sample classified as low income by the PNDR, 300 are in growth clubs that are statistically sensitive to the effects of the FNE (270 in group 2 and 30 in group 3). Thus, if the low-income municipalities receive the same volume of financing per capita in linear fashion, the expected effectiveness is around $79.1 \%$. From that same perspective, estimations of effectiveness in the case of the municipalities classified as stagnated, dynamic and high income, are $83.4 \%, 75.7 \%$ and $59.4 \%$, respectively.

The relatively lower effectiveness in the highincome municipalities confirms the tendency of the PNDR to prioritize (albeit not exclusively, it should be

20 There is also a difference in terms of the reference year of the PNDR ranking by initial per capita income and the initial per capita GDP of the growth clubs formed. 
TABLE 4

Classification of municipalities. Growth clubs according to the PNDR

\begin{tabular}{|c|c|c|c|c|c|}
\hline \multirow{2}{*}{ Clubs according to GDP brackets } & \multicolumn{4}{|c|}{ Regional National Development Policy (PNDR) } & \multirow{2}{*}{ Tota } \\
\hline & Low income & Stagnated & Dynamic & High income & \\
\hline $\mathrm{R} \$ 2143(1)$ & $\begin{array}{r}74(36,3) \\
(19,5)\end{array}$ & $\begin{array}{r}54(26,5) \\
(13,2)\end{array}$ & $\begin{array}{r}76(37,3) \\
(18,6)\end{array}$ & $\begin{array}{r}0(0) \\
(0)\end{array}$ & 204 \\
\hline $\mathrm{R} \$ 2$ 143-R\$ $3866(2)$ & $\begin{array}{r}270(34,1) \\
(71,2)\end{array}$ & $\begin{array}{r}262(33,1) \\
(64,1)\end{array}$ & $\begin{array}{r}253(31,9) \\
(62,0)\end{array}$ & $\begin{array}{r}7(0,9) \\
(21,9)\end{array}$ & 792 \\
\hline $\mathrm{R} \$ 3$ 866-R\$ 7406 (3) & $\begin{array}{r}30(16,9) \\
(7,9)\end{array}$ & $\begin{array}{r}79(44,6) \\
(19,3)\end{array}$ & $\begin{array}{r}56(31,6) \\
(13,7)\end{array}$ & $\begin{array}{r}12(6,8) \\
(37,5)\end{array}$ & 177 \\
\hline $\mathrm{R} \$ 7406(4)$ & $\begin{array}{r}5(9,1) \\
(1,3)\end{array}$ & $\begin{array}{r}14(25,5) \\
(3,4)\end{array}$ & $\begin{array}{r}23(41,8) \\
(5,6)\end{array}$ & $\begin{array}{r}13(23,6) \\
(40,6)\end{array}$ & 55 \\
\hline Total municipalities & 379 & 409 & 408 & 32 & 1228 \\
\hline
\end{tabular}

Source: prepared by the authors.

1) Per capita GDP below $\mathrm{R} \$ 2,143$.

2) Per capita GDP equal to or greater than $R \$ 2,143$ and below $R \$ 3,866$.

3) Per capita GDP equal to or greater than $R \$ 3,866$ and below $R \$ 7,406$.

4) Per capita GDP equal to or greater than $R \$ 7,406$.

GDP: gross domestic product.

stressed) the municipalities of the first three categories (low-income, stagnated and dynamic), since the return to the fund would be greater in those municipalities. Moreover, the discovery of differentiated effects between the municipalities with different economic levels raises the need for more careful monitoring of municipalities that do not adequately respond to the investment flows.

As the groups include municipalities with low and high per capita incomes, attention should be paid to the specific local factors that hinder investment-induced growth. Among supply-side factors, appropriate marketing and monitoring of projects are fundamental for them to have the expected repercussions. In that connection, part of the FNE resources destined for family farmers (PRONAF) was recently put under systemized monitoring by trade

\section{VI}

\section{Final thoughts}

This article has sought to verify the effects of the Northeast Financing Constitutional Fund on the economic growth of northeastern municipalities in the decade of 2000. To that end, it used an empirical framework based on growth models (Barro and Sala-i-Martin, 1991) which made it possible to form clubs of convergence and heterogeneity in terms of the effects of the co-factors, according to the municipality's initial development level (Durlauf and Johnson, 1995). agents in micro finance programmes (the AgroAmigo programme). This could be an encouraging factor, particularly for low-income municipalities in which the agriculture sector has a large share. As this programme was consolidated after the period researched in this paper, the growth dynamics in the Northeast should be updated in future research.

On the demand side, the structured organization of local economic agents is also important to enable them to develop and apply their business skills on a coordinated basis. For that purpose, interaction should be promoted between local government, financing agencies, and technical and scientific support institutions, to ensure that the investment becomes a sustained factor of production and productivity, rather than a mechanism for reproducing the existing economic scenario.
One of the advantages of that nonlinear model consists of being able to determine, through an endogenous selection process, the composition of the "clubs" of municipalities displaying growth patterns that are mutually similar and (statistically) different from those in other groups. A test of that possibility with respect to the growth of per capita GDP in the municipalities of the Northeast in the period 2002-2008, revealed the existence of four convergence clubs with differentiated 
FNE effects, discriminated according to the initial per capita GDP level of the municipalities.

The effects of the FNE were not statistically significant in municipalities with a per capita GDP of up to $\mathrm{R} \$ 2,143$ (204 municipalities), and in those with initial per capita GDP is above $\mathrm{R} \$ 7,406$ (55 municipalities). In contrast, positive and statistically significant effects were recorded in municipalities with intermediate per capita GDP levels, between $\mathrm{R} \$ 2,143$ and $\mathrm{R} \$ 3,866$ (792 municipalities) and between $\mathrm{R} \$ 3,866$ and $\mathrm{R} \$ 7,406$ (177 municipalities). In the first group, a $10 \%$ increase in the volume of FNE resources per capita would result in an average increase of 0.78 percentage points in the GDP growth rate, whereas in the second group, the corresponding increase would be 1.09 percentage points. These are considerable effects, given the history of growth rates in the region.

Overall, the results show that the FNE had a positive average effect on growth in the municipalities of the Northeast in the period 2002-2008. Although the general positive effect is important for legitimizing this regional policy tool, account needs to be taken of methodological caveats and the specific characteristics of the results.

When specifying the econometric equation for estimating the effects of the FNE in the municipalities, steps were taken to follow the empirical literature on economic growth, which is based on models designed for cross-section data. Although an evaluation using panel data could be richer given the multidimensional nature of the data, the limited availability of information prevented such an evaluation being made.

Another constraint, also related to data availability, is the absence of the explanatory variable "physical capital", which is generally present in studies of this type. It is hoped that the variable "households with piped water", as a proxy for municipal physical capital, partially captures the variation and largely reduces the potential for biases in the estimations. It would be advisable to conduct specification tests to research this problem in greater detail; but, as models with threshold effects are being used, those techniques have not yet been proposed. Lastly, although it is possible to include more than one threshold variable when forming the groups of municipalities in the estimation process (as happens in some studies that use models with that type of nonlinearity) this would make the analysis more complex in terms of identifying the factor that determines the formation of a convergence group. The use of the variable "initial per capita income" as the only threshold variable in economic growth models is a virtually universal practice.

Future complementary studies could estimate growth models at other levels of regional aggregation (for example, micro-regions), to capture any regional scale effect or reduce potential problems in measuring variables in the municipal sector. ${ }^{21}$

In terms of the specific results of the study, the absence of significant growth effects in the lowest-income municipalities highlights the need to more effectively monitor the amount and quality of the resources channelled to them, and also the local factors that pose obstacles to economic growth. The same reasoning also applies to the highest-income municipalities.

\footnotetext{
21 This potential problem is addressed in Resende (2012a).
}

\section{ANNEX}

TABLE A.1

\section{Explanatory variables}

\begin{tabular}{|c|c|c|c|c|}
\hline Variable & Definition & Source & Mean & $\begin{array}{l}\text { Standard } \\
\text { deviation }\end{array}$ \\
\hline$F_{i}$ & $\begin{array}{l}\text { Average total FNE financing per capita in the period 2002-2006 } \\
(R \$ \text { at } 2007 \text { prices })\end{array}$ & $\mathrm{BNB}$ & 64.01 & 234.99 \\
\hline & Municipal per capita GDP in 2002 ( $R \$$ at 2007 prices) & Ipeadata & 3712.06 & 7395.23 \\
\hline$(n+\delta+d)$ & $\begin{array}{l}\text { Average rate of population growth between } 2002 \text { and } 2008 \text {, } \\
\text { plus } 0.05 \text { for a technological growth and depreciation }\end{array}$ & Ipeadata & 0.0572 & 0.01 \\
\hline$e d u$ & Average years of schooling among 25 -year olds & Ipeadata & 2.90 & 0.83 \\
\hline gov & Average ratio between current expenditure and municipal GDP in 2002 & Ipeadata & 45.59 & 19.32 \\
\hline dist & Distance of the municipality from the respective state capital & Ipeadata & 226.58 & 148.89 \\
\hline opc & Total credit operations per capita in 2002 ( $R \$$ at 2007 prices $)$ & Central Bank of Brazil & 436.86 & 4258.79 \\
\hline semi & Variable equal to 1 if located in the semiarid zone, 0 otherwise. & Ipeadata & 0.63 & 0.48 \\
\hline
\end{tabular}

Source: prepared by the authors.

FNE: Northeast Financing Constitutional Fund.

GDP: gross domestic product.

BNB: Banco do Nordeste do Brasil. 
TABLE A. 2

Estimations of the global models and the model with threshold effect without control variables

(Per capita GDP)

\begin{tabular}{|c|c|c|c|}
\hline \multirow{3}{*}{ Variables } & \multirow{3}{*}{ Global } & \multicolumn{2}{|c|}{ Groups } \\
\hline & & \multicolumn{2}{|c|}{ Threshold } \\
\hline & & $y_{i, 0}<8.32$ & $y_{i, 0}>8.32$ \\
\hline intercept & $\begin{array}{c}1.282 * \\
(5.317)\end{array}$ & $\begin{array}{c}3.701 * \\
(11.569)\end{array}$ & $\begin{array}{c}-0.209 \\
(-0.373)\end{array}$ \\
\hline$F_{i}$ & $\begin{array}{c}0.082 * \\
(4.457)\end{array}$ & $\begin{array}{c}0.067 * \\
(4.918)\end{array}$ & $\begin{array}{c}0.117^{*} \\
(2.085)\end{array}$ \\
\hline $\ln \left(y_{i, 0}\right)$ & $\begin{array}{c}-0.160^{*} \\
(-5.458)\end{array}$ & $\begin{array}{r}-0.462^{*} \\
(-11.449)\end{array}$ & $\begin{array}{c}-0.002 \\
(-0.031)\end{array}$ \\
\hline No. of observations & 1790 & 1493 & 297 \\
\hline$S^{2}$ & 0.126 & 0.088 & 0.28 \\
\hline
\end{tabular}

Source: prepared by the authors.

* Significant at $5 \%$.

$t$-statistics in parentheses.

$S^{2}$ : sample variance of the model.

GDP: gross domestic product.

TABLE A.3

Estimations of the global models and threshold effect through control variables (Per capita GDP)

\begin{tabular}{|c|c|c|c|c|c|}
\hline \multirow{2}{*}{ Variables } & \multirow[b]{2}{*}{ Global } & \multicolumn{4}{|c|}{ Groups } \\
\hline & & $y_{i, 0}<7.67$ & $7.67 \leq y_{i, 0}<8.26$ & $8.26 \leq y_{i, 0}<8.91$ & $y_{i, 0}>8.91$ \\
\hline intercept & $\begin{array}{c}0.896^{*} \\
(2.282)\end{array}$ & $\begin{array}{c}-0.199 \\
(-0.170)\end{array}$ & $\begin{array}{c}3.368 * \\
(7.565)\end{array}$ & $\begin{array}{c}2.479 \\
(0.974)\end{array}$ & $\begin{array}{c}3.018 \\
(0.876)\end{array}$ \\
\hline$F_{i}$ & $\begin{array}{c}0.085^{*} \\
(3.242)\end{array}$ & $\begin{array}{c}-0.007 \\
(-0.441)\end{array}$ & $\begin{array}{c}0.078^{*} \\
(4.606)\end{array}$ & $\begin{array}{l}0.109 * * \\
(1.958)\end{array}$ & $\begin{array}{c}0.173 \\
(1.588)\end{array}$ \\
\hline $\ln \left(y_{i, 0}\right)$ & $\begin{array}{c}-0.088^{*} \\
(-2.053)\end{array}$ & $\begin{array}{c}0.068 \\
(0.402)\end{array}$ & $\begin{array}{c}-0.419^{*} \\
(-8.334)\end{array}$ & $\begin{array}{l}-0.421 * * \\
(-1.665)\end{array}$ & $\begin{array}{c}-0.5668 \\
(-2.200)\end{array}$ \\
\hline$(n+\delta+d)_{i}$ & $\begin{array}{c}-0.127 * \\
(-2.876)\end{array}$ & $\begin{array}{c}-0.157 * \\
(-3.746)\end{array}$ & $\begin{array}{c}-0.120 * \\
(-2.683)\end{array}$ & $\begin{array}{l}-0.377^{*} \\
(-2.920)\end{array}$ & $\begin{array}{c}1.496 \\
(1.493)\end{array}$ \\
\hline$e d u_{i}$ & $\begin{array}{c}0.044 \\
(1.122)\end{array}$ & $\begin{array}{c}0.002 \\
(0.030)\end{array}$ & $\begin{array}{r}0.148^{*} \\
(3.408)\end{array}$ & $\begin{array}{c}0.091 \\
(0.688)\end{array}$ & $\begin{array}{c}0.398 \\
(0.997)\end{array}$ \\
\hline infra $_{i}$ & $\begin{array}{c}-0.029^{*} \\
(-2.313)\end{array}$ & $\begin{array}{l}-0.023^{* *} \\
(-1.748)\end{array}$ & $\begin{array}{c}-0.031^{*} \\
(-2.213)\end{array}$ & $\begin{array}{c}0.121 \\
(1.556)\end{array}$ & $\begin{array}{c}-0.052 \\
(-0.208)\end{array}$ \\
\hline gov $_{i}$ & $\begin{array}{c}-0.089^{*} \\
(-2.265)\end{array}$ & $\begin{array}{l}-0.039 \\
(-0.819)\end{array}$ & $\begin{array}{l}-0.073 * \\
(-2.245)\end{array}$ & $\begin{array}{c}-0.137 \\
(-1.479)\end{array}$ & $\begin{array}{c}0.838 * \\
(2.009)\end{array}$ \\
\hline dist $_{i}$ & $\begin{array}{c}0.006 \\
(0.015)\end{array}$ & $\begin{array}{c}0.005 \\
(1.079)\end{array}$ & $\begin{array}{l}-0.001 \\
(-0.101)\end{array}$ & $\begin{array}{c}0.032 \\
(1.062)\end{array}$ & $\begin{array}{c}0.048 \\
(0.566)\end{array}$ \\
\hline$o p c_{i}$ & $\begin{array}{c}0.004 \\
(0.909)\end{array}$ & $\begin{array}{c}0.005 \\
(1.080)\end{array}$ & $\begin{array}{l}0.006^{* *} \\
(1.666)\end{array}$ & $\begin{array}{c}-0.005 \\
(-0.523)\end{array}$ & $\begin{array}{c}0.044 \\
(0.698)\end{array}$ \\
\hline semi $_{i}$ & $\begin{array}{c}-0.077^{*} \\
(-3.089)\end{array}$ & $\begin{array}{c}0.010 \\
(0.310)\end{array}$ & $\begin{array}{c}-0.071^{*} \\
(-2.634)\end{array}$ & $\begin{array}{c}-0.141 \\
(-1.386)\end{array}$ & $\begin{array}{l}-0.290^{*} \\
(3.018)\end{array}$ \\
\hline No. of observations & 1228 & 204 & 792 & 177 & 55 \\
\hline$S^{2}$ & 0.107 & 0.046 & 0.057 & 0.129 & 0.806 \\
\hline
\end{tabular}

Source: prepared by the authors.

* Significant at $5 \%$;* significant at $10 \%$.

$t$-statistics in parentheses.

$S^{2}$ : sample variance of the model.

GDP: gross domestic product. 


\section{Bibliography}

Aghion, P., P. Howitt and D. Mayer-Foulkes (2004), "The effect of financial development on convergence: theory and evidence", NBER Working Paper, No. 10358, Cambridge, Massachusetts, National Bureau of Economic Research.

Azariadis, C. and A. Drazen (1990), "Threshold externalities in economic development", The Quarterly Journal of Economics, vol. 105, No. 2, Oxford, Oxford University Press.

Banco do Nordeste (2011), Fundo Constitucional de Financiamento do Nordeste - FNE. Relatório de resultados e impactos: Exercício de 2011 - Primeiro semestre.

Barro, R. and X. Sala-i-Martin (1992), "Convergence", Journal of Political Economy, vol. 100, No. 2, Chicago, University of Chicago Press.

(1991), "Convergence across states and regions", Brookings Papers on Economic Activity, vol. 22, No. 1, Washington, D.C., The Brookings Institution.

Baumol, J.W. (1986), "Productivity growth, convergence, and welfare: what the long-run data show", The American Economic Review, vol. 76, No. 5, Nashville, Tennessee, American Economic Association, December.

Bayoumi, T. and O. Melander (2008), "Credit matters: empirical evidence on U.S. macro-financial linkages", IMF Working Paper, No. 08/169, Washington, D.C., International Monetary Fund.

Bencivenga, V.R. and B.D. Smith (1991), "Financial intermediation and endogenous growth", Review of Economic Studies, vol. 58, No. 2, Oxford, Oxford University Press.

Bourguignon, F. (2002), "The distributional effects of growth: case studies vs. cross-country regressions", DELTA Working Paper, No. 2002-23, Paris, DELTA (École normale supérieure).

Boyd, J.H. and E.C. Prescott (1986), "Financial intermediarycoalitions", Journal of Economic Theory, vol. 38, No. 2, Amsterdam, Elsevier.

Brazil (1999), "Lei no 9.808, de 20 de julho de 1999. Define diretrizes e incentivos fiscais para o desenvolvimento regional e dá outras providências" [online] http://www.planalto.gov.br.

Cabral, E.C.S. (2008), "Convergência de renda per capita entre os Estados brasileiros de 1939 a 2004", thesis, Brasilia, University of Brasilia.

Chinelatto Neto, A. (2007), "Relações entre crédito e crescimento econômico no Brasil, 2000 a 2006", thesis, Viçosa, Minas Gerais, Federal University of Viçosa.

Dall'Erba, S., R. Guillain and J.L. Gallo (2011), "Impact of structural funds on regional growth: how to reconsider a 7 year-old black-box", Working Paper.

Dall'Erba, S. and H.L.F. de Groot (2006), "A meta-analysis of EU regional policy evaluation", paper presented at the 53rd Annual North American Meetings of the RSAI, Toronto.

De Gregorio, J. and P.E. Guidotti (1995), "Financial development and economic growth", World Development, vol. 23, No. 3, Amsterdam, Elsevier.

Durlauf, S.N. and P.A. Johnson (1995), "Multiple regimes and crosscountry growth behavior", Journal of Applied Econometrics, vol. 10, No. 4, John Wiley \& Sons, Ltd.

Durlauf, S.N., P.A. Johnson and J.R.W. Temple (2004), "Growth econometrics", Vassar College Department of Economics Working Paper, No. 61.

Durlauf, S.N. and D.T. Quah (1999), "The new empirics of economic growth", Handbook of Macroeconomics, J.B. Taylor and M. Woodford (ed.), vol. 1, Amsterdam, Elsevier.

Goldsmith, R.W. (1969), Financial Structure and Development, New Haven, Connecticut, Yale University Press.

Greenwood, J. and B. Jovanovic (1990), "Financial development, growth and the distribution of income", Journal of Political Economy, vol. 98, No. 5, Chicago, University of Chicago Press.
Hansen, B.E. (2000), "Sample splitting and threshold estimation", Econometrica, vol. 68, No. 3, New York, The Econometric Society.

(1996), "Inference when a nuisance parameter is not identiffed under the null hypothesis", Econometrica, vol. 64, No. 2, New York, The Econometric Society.

Jappelli, T. and M. Pagano (1994), "Saving, growth and liquidity constraints", Quarterly Journal of Economics, vol. 109, No. 1, Cambridge, Massachusetts, The MIT Press.

Keynes, J.M. (1936), General Theory of Employment, Interest, and Money, London, Macmillan.

King, R.G. and R. Levine (1993), "Finance, entrepreneurship, and growth", Journal of Monetary Economics, vol. 32, No. 3, Amsterdam, Elsevier.

Levine, R. (2004), "Finance and growth: theory and evidence", NBER Working Paper, No. 10766, Cambridge, Massachusetts, National Bureau of Economic Research.

(1992), "Financial structure and economic development", Policy Research Working Paper Series, No. 849, Washington, D.C., World Bank.

Mankiw, N., G.D. Romer and D.N. Weil (1992), "A contribution to the empirics of economics", Quarterly Journal of Economics, vol. 107, No. 2, Oxford, Oxford University Press.

Marques Jr., T.E. and S.S. Porto Jr. (2004), "Desenvolvimento financeiro e crescimento econômico no Brasil - Uma avaliação econométrica", Trabalho para Discussão, No. 11, Postgraduate Programme in Economics/Federal University of Rio Grande do Sul (UFRGS).

Matos, O.C. (2002), "Desenvolvimento do sistema financeiro e crescimento econômico no Brasil: Evidência de causalidade", Trabalho para discussão, No. 49, Central Bank of Brazil.

McKinnon, R. (1973), Money and Capital in Economic Development, Washington, D.C., The Brookings Institute.

Mesquita, A.M. (1996), "Avaliação econômica do Fundo Constitucional de Financiamento do Nordeste (FNE)", Dissertação de Mestrado, Minas Gerais, Federal University of Minas Gerais.

Ministry of National Integration (2010), 20 Anos de Fundos Constitucionais de Financiamento (FCO-FNE-FNO), Brasilia. (2005), Plano Nacional de Desenvolvimento Regional, Brasilia.

Oliveira, H.C. de and E.P. Domingues (2005), "Considerações sobre o impacto dos Fundos Constitucionais de Financiamento do Norte e do Centro-Oeste na redução da desigualdade regional no Brasil", Anais do XXXIII Encontro Nacional de Economia, Rio de Janeiro, National Association of Post-Graduate Centres of Economics (ANPEC).

Oliveira, J.L. and others (2011), "Dinâmica regional e convergência de renda: um estudo para os municípios cearenses no período recente", Dinâmica regional e convergência de renda. Uma análise para os municípios brasileiros selecionados no período 2002-2007, Brasilia, Institute of Applied Economic Research (IPEA).

Penna, C.M. (2011), "Convergência dos PIBs estaduais per capita no Brasil", thesis, Fortaleza, CAEN.

Phillips, P.C.B. and D. Sul (2007), "Transition modeling and econometric convergence tests", Econometrica, vol. 75, No. 6, New York, The Econometric Society.

Resende, G.M. (2012a), "Measuring micro- and macro-impacts of regional development policies: the case of the Northeast Regional Fund (FNE) industrial loans in Brazil, 2000-2006", Regional Studies, vol. 48, No. 4, Taylor \& Francis.

- (2012b), "Micro e macroimpactos de políticas de desenvolvimento regional: o caso dos empréstimos do FNEindustrial no estado do Ceará", Texto para Discussão, No. 1777, Rio de Janeiro, Institute of Applied Economic Research (IPEA). 
Rocha, B.P. and M.I. Nakane (2007), "Sistema financeiro e desenvolvimento econômico: evidências de causalidade em um painel para o Brasil", Anais do XXXV Encontro Nacional de Economia, Rio de Janeiro, National Association of PostGraduate Centres of Economics (ANPEC).

Rodrigues, M.T. (1998), "Eficiência alocativa do Fundo Constitucional de Financiamento do Nordeste (FNE): uma visão de insumoproduto", Dissertação, São Paulo, Luiz de Queiroz School of Agriculture/University of São Paulo.

Schumpeter, J.A. (1934), The Theory of Economic Development, Cambridge, Massachusetts, Harvard University Press.

Shaw, E.S. (1973), Financial Deepening in Economic Development, New York, Oxford University Press.

Silva, A.M., G.M. Resende and R. Silveira Neto (2009), "Eficácia do gasto público: uma avaliação do FNE, FNO e FCO", Estudos econômicos, vol. 39, No. 1, São Paulo.

Soares, R., J. Sousa and A. Pereira Neto (2009), "Avaliação de impacto do FNE no emprego, na massa salarial e no salário médio em empreendimentos financiados", Revista Econômica do Nordeste, vol. 40, No. 1, Fortaleza, Banco do Nordeste.

Trompieri Neto, N., I. Castelar and F.C. Linhares (2008), "Convergência de renda dos estados brasileiros: uma abordagem de painel dinâmico com efeito threshold", Anais do XXXVI Encontro Nacional de Economia, Rio de Janeiro, National Association of Post-Graduate Centres of Economics (ANPEC).

Tsangarides, C.G. (2005), "Growth empirics under model uncertainty: is Africa different?, IMF Working Papers, No. 05/18, Washington, D.C., International Monetary Fund. 